\title{
Everything you always wanted to know about sex and Neurology: neurological disability and sexuality
}

\author{
Todo lo que siempre quiso saber sobre sexo y Neurologia pero nunca se atrevió a \\ preguntar: estudio sobre discapacidad neurologica y sexualidad \\ Alejandro Nasimbera1, Julieta Rosales', Berenice Silva², Ricardo Alonso², Natalia Bohorquez 3,4, Sandra Lepera ${ }^{3}$, \\ Nelida Garretto 5 , Tomoko Arakaki ${ }^{5}$, Orlando Garcea², Raul Rey ${ }^{3}$, Cecilia Quarracino ${ }^{6}$, Gabriel E. Rodriguez ${ }^{4}$
}

\begin{abstract}
Chronic neurological disorders generate disabilities affecting multiple aspects of life, including sexuality. Objective: To describe the presence of sexual dysfunction and comorbidities in a population with chronic neurological disorders. To analyze the relationship between disability and sexual dysfunction. Methods: A cross-sectional case-control study was carried out. Patients with amyotrophic lateral sclerosis (ALS), multiple sclerosis (MS), Parkinson's disease (PD), and stroke of at least one year since the onset of symptoms were included, and compared with controls with no neurological disease, matched by age and sex. Results: We included 71 participants: 29 controls, with a mean age of 49.4 years, and 42 patients with a mean age of 53.8 years. Sexual dysfunction was present in $22.5 \%$ of the controls and $77.5 \%$ of the patients. A statistically significant relationship between sexual dysfunction and disability was found in the logistic regression analysis (OR $=20.38,95 \% \mathrm{Cl}: 2.5-165.86)$. Conclusions: Disability proved to be the main variable related to the presence of sexual dysfunction. Patients with ALS had the worst rates of sexual dysfunction. Patients with MS were similar to the control group. As for the PD group, no patient had normal sexuality. Finally, in stroke patients, the presence of comorbidities and their treatment may have negatively influenced sexuality. These findings showed that patients with chronic neurological diseases have sexual dysfunction and underscore the need for neurologists to know and address this problem.
\end{abstract}

Keywords: stroke; amyotrophic lateral sclerosis; Parkinson disease; multiple sclerosis; sexuality.

\begin{abstract}
RESUMO
Las enfermedades neurológicas crónicas generan discapacidad afectando múltiples aspectos de la vida, incluida la sexual. Objetivo: Describir en una población con enfermedades neurológicas crónicas la presencia de disfunción sexual y posibles comorbilidades acompañantes. Analizar la relación entre discapacidad y disfunción sexual. Métodos: Se realizó un estudio transversal de tipo casos y controles. Se incluyeron pacientes con Esclerosis Lateral Amiotrófica (ELA), Esclerosis Múltiple (EM), enfermedad de Parkinson (EP) y secuelados por enfermedad cerebrovascular (SACV) de al menos un año de evolución, controlando con sujetos sin enfermedad neurológica pareados por edad y sexo. Resultados: Se incluyeron 71 sujetos: 29 controles, con una edad media 49,4 años y 42 casos con una edad media de 53,8 años. Presentaron disfunción sexual el 22,5\% de los controles y el 77,5\% de los casos. En el análisis por regresión logística se encontró una relación estadísticamente significativamente entre disfunción sexual y discapacidad. (OR = 20.38, IC95\%: 2.5-165.86). Conclusiones: La discapacidad demostró ser la principal variable relacionada con la presencia de disfunción sexual. Los enfermos con ELA fueron los que peores índices de disfunción sexual presentaron. Los pacientes con EM se comportaron de forma similar al grupo control. En cuanto al grupo de EP todos los pacientes tuvieron algún trastorno en su sexualidad. Por último, en sACV la presencia de comorbilidades y su tratamiento podrían influir negativamente en la sexualidad. Estos hallazgos evidencian que la disfunción sexual está presente en los pacientes con enfermedades neurológicas crónicas y confirma la necesidad de conocer este problema por parte de los neurólogos.
\end{abstract}

Palabras clave: accidente cerebrovascular; esclerosis amiotrófica lateral; enfermedad de Parkinson; esclerosis múltiple; sexualidad.

\footnotetext{
1 Hospital JM Ramos Mejia, División Neurología, Buenos Aires, Argentina;

${ }^{2}$ Hospital JM Ramos Mejia, Clínica Enfermedades Desmielinizantes, Buenos Aires, Argentina;

${ }^{3}$ Hospital JM Ramos Mejia, Clínica Enfermedades Cerebrovasculares, Buenos Aires, Argentina;

${ }^{4}$ Hospital JM Ramos Mejia, Clínica Enfermedades de Neurona Motora, Buenos Aires, Argentina;

${ }^{5}$ Hospital JM Ramos Mejia, Clínica Movimientos Anormales, Buenos Aires, Argentina;

${ }^{6}$ Instituto de Investigaciones Medicas Doctor Alfredo Lanari, División Neurología, Buenos Aires.
}

Correspondence:Alejandro Nasimbera; Neurology Division, Hospital JM Ramos Mejía; Urquiza 609 CP 1221; Buenos Aires, Argentina; E-mail: alejandro_ nasimbera@hotmail.com

Conflict of interest: There is no conflict of interest to declare.

Received 13 December 2017; Received in final form 31 March 2018; Accepted 03 April 2018. 
Patients with chronic neurological diseases live with disorders that affect all aspects of their life and environment ${ }^{1}$.

Sexual dysfunction may be one of these many disorders. The causes that generate sexual dysfunction can be classified as: a) primary - a product of a direct injury of the anatomical structures involved in sexuality (nerves, pathways, cortex); b) secondary to physical changes resulting from the disease (e.g. muscular atrophy, spasticity, chronic fatigue) and c) tertiary, due to psychosocial changes in the patient (e.g. low self-esteem, depression, discordant relationships $)^{2,3}$.

Amyotrophic lateral sclerosis (ALS) is a neurodegenerative disease that affects the pyramidal pathway along its first and second motor neurons. The survival after diagnosis is approximately $20 \%$ at three to five years ${ }^{4}$. A reduction in both the interest and the sexual activity of patients with ALS and their partners has been reported ${ }^{5}$.

Multiple sclerosis (MS) is a chronic, autoimmune disease that affects the central nervous system (CNS) by dual mechanisms: inflammatory and degenerative, leading to demyelination and subsequent loss of neurons. It is the main cause of nontraumatic neurological disability in young adults ${ }^{6}$. Sexual dysfunction is one of the main problems reported by MS patients; an Iranian study showed that $40-80 \%$ of women with MS had some degree of sexual dysfunction ${ }^{3}$.

Parkinson's disease (PD) is one of the most common neurodegenerative diseases in the elderly, affecting $1 \%$ of patients over 60 years and $0.3 \%$ of the general population. It is manifested by motor and nonmotor symptoms as a result of nigrostriatal dopaminergic denervation and extranigral neurodegeneration ${ }^{7}$. In Israel, one study found that both women and men with Parkinson's disease show lower levels of desire and arousal, and a higher rate of erectile dysfunction and premature ejaculation ${ }^{8}$.

Cerebrovascular diseases (CVDs), as well as their sequelae, are the world's leading cause of disability with more than five million people affected worldwide annually ${ }^{9,10}$. In patients with stroke sequelae, negative changes in their sexual life have been described ${ }^{11}$.

Chronic diseases have a negative influence on intimate relationships and level of sexual satisfaction ${ }^{12}$ and many patients and their partners are forced to modify their sexual habits as a consequence of their condition ${ }^{13}$.

The CNS is actively involved in sexuality. Studies using functional nuclear magnetic resonance imaging and positron emission tomography scans have shown that sexual stimuli cause activation of the middle preoptic area and the anterior hypothalamus, two critical areas, and triggers of animal precopulatory activity ${ }^{1,14,15,16,17}$. The studies also demonstrate that these areas are not the only ones involved in human sexual behavior and confirm the activation and deactivation of multiple brain areas in response to excitatory and inhibitory stimuli. These include the cingulate cortex, temporal cortex, insula, caudate nucleus, hypothalamus, and the cerebellum ${ }^{1,15,16,17}$. The fundamental circuit involved in sexuality is the middle preoptic area, paraventricular nucleus and paragigantocellular nucleus, as well as their interconnections, the spinal cord, and the genital and extragenital organs involved in sexual behavior. However, there are excitatory and inhibitory influences from multiple central areas that modulate sexual response according to the circumstances. The hypothalamus plays an important role, since it is the link between the nervous system and the endocrine system and is involved in the control of certain basic behaviors, such as appetite, aggressiveness and sexual arousal ${ }^{1,16,17,18}$.

The complexity of control powered by the CNS is compounded by the fundamental role played by the peripheral nervous system in the anatomy of sexuality. The associated peripheral nerves and plexuses connect the sexual organs to the $\mathrm{CNS}^{1,14,15}$. In women, the pelvic organs, including the internal genitals, are innervated by the autonomic nervous system through the upper, middle (inconstant) and inferior hypogastric plexus. The external genitals, muscles and tissues of the perineum are innervated mainly by the pudendal nerve, formed by the anterior branches of the sacral nerves II, III and IV. The superficial branches of this nerve provide sensory innervation to the vaginal lips and clitoris ${ }^{1,18,19,20}$. In men, the nerves that innervate the genitals are branches of the pudendal nerve and of the cavernous nerves. The pudendal nerve is responsible for the motor and sensory innervation of the external genitalia. Also, the cavernous nerves are a combination of sympathetic and parasympathetic afferent fibers, and constitute the autonomic nerves of the penis. These nerves are responsible for the innervation of the erectile component of the penis and ejaculation. The sympathetic center is at the level of the spinal segments T10 to L3; the preganglionic neurons involved in the efferent parasympathetic activity of the penis are located in the gray intermediate zone of the spinal cord, between the 2nd and 4th sacral vertebra ${ }^{1,17,18,19,21}$.

Sexuality, in its anatomical and functional sense, is not restricted exclusively to the sexual organs. Furthermore, it incorporates the whole economy of the nervous system, including the sense organs, connecting pathways and CNS processing capacity ${ }^{18,19,20,21}$.

Bearing this in mind, we analyzed the association between disability resulting from four neurological diseases (ALS, MS, PD, CVD) and sexuality, measured with specific scales. We considered that the impact of disability was not reduced to the mere reduction of the patient's mobility, but affected multiple spheres at the psychic and social level, generating a significant impact on sexuality ${ }^{1,21,22,23,24,25,26}$.

The objective of our study was to describe the presence of sexual dysfunction and possible associated comorbidities in a population with chronic neurological diseases, and relate the disability to sexual activity dysfunction. 


\section{METHODS}

We conducted a case-control study on patients with ALS, MS, PD and non-acute stroke (at least one year post-event) and disease-free sex-aged matched controls.

Internationally-validated disability scales were used on each pathology. The Amyotrophic Lateral Sclerosis Functional Rating Scale was performed on ALS patients. It is a 12-item scale that addresses bulbar, respiratory and motor involvement during activities of daily living ${ }^{27,28}$. Patients with MS were rated using the Expanded Disability Status Scale, which scores patients' abilities through eight disease-targeted functional systems ${ }^{29}$. To grade disability in PD patients we used the Movement Disorder Society - Unified Parkinson Disease Rating Scale ${ }^{30}$. Finally, we scored non-acute stroke patients with the Modified Rankin Scale ${ }^{31}$. The scales were subclassified in the followings ranges to validate the disability results; ALS-Functional Rating Scale: 48 points = without disability, 37-47 = mild disability, 25-36 = moderate disability, $\leq 24$ = severe disability; Expanded Disability Status Scale: 0 points $=$ without disability, $1-3=$ mild disability, 3.5-5.5 = moderate disability, $\geq 6$ = severe disability; Unified Parkinson Disease Rating Scale: 0-50 points: without disability, 51-100 $=$ mild disability, 101-150 = moderate disability and $\geq 151$ severe disability; Modified Rankin Scale: 0 points = without disability, $1=$ mild disability, $2-3=$ moderate disability, $4-5$ $=$ severe disability. We then created the dichotomous variable "disability", which scored 1 for the patients who were rated as moderate or severe.

Sexual function was rated both in affected and control participants with the International Index Erectile Function ${ }^{32}$ for men and the Female Sexual Function Index ${ }^{33}$ for women. Both scales address sexuality with a global scope and identify the different areas that can be affected. Of these, we focused on global satisfaction and orgasm ${ }^{32,33}$. The International Index Erectile Function scale was subclassified as follows. no sexual dysfunction $=65$ to 75 points; 1 ; mild sexual dysfunction $=43$ to 64 points; 2 : moderate sexual dysfunction $=21$ to 43 points and; severe sexual dysfunction $=$ between 0 and 20 points. The Female Sexual Function Index scale was subclassified as follows; without sexual dysfunction $=26$ to 36 points; 1 : mild sexual dysfunction $=19$ to 25 points; 2 : moderate sexual dysfunction $=10$ to 18 points and 3 ; severe sexual dysfunction $=<$ 10 points. We also created the dichotomous variable "sexual dysfunction", which scored 0 for those patients with none or mild impairment.

The Beck Inventory was performed on every patient to screen for depression, we considered depression as $\geq 10^{34}$.

The study was approved by the ethical committee of our institution and all patients agreed to participate in the study and signed an informed consent form.

We used the SPSS V.20 software for data analysis. Chisquare, Student's-t and logistic regression tests were used when appropriate. Statistical significance was set at $5 \%$.

\section{RESULTS}

We included 42 patients ( 20 men) with a mean age of 53.8 (SD: 11.24) and 29 controls (12 men) with a mean age of 49.4 (SD: 19.33). Among the patients, nine had ALS, 12 MS, 13 PD and eight a history of stroke. Sexual dysfunction was present in $77.5 \%$ of the patients and $22.5 \%$ of controls (Tables 1 and 2).

We performed a logistic regression with "sexual dysfunction" as the dependent variable and age, depression and "disability" as the independent variables. All of them had statistical significance, both in the univariate and the multivariate analyses $(\mathrm{p}<0.05)$. "Disability" had the greatest odds ratio (20.38, CI 95\%: 2.5-165.86), followed by depression (8.83, CI 95\%: 1.67-46.76) and age (1.13, CI 95\%: 1.04-1.23).

With regard to sexual dysfunction, $69 \%$ of controls had none, $10.3 \%$ had mild sexual dysfunction and $20.7 \%$ had severe sexual dysfunction. In patients with ALS, 55.6\% had severe sexual dysfunction, $22.2 \%$ had moderate sexual dysfunction and $22.2 \%$ had no sexual dysfunction at all. Considering those with MS, $66.7 \%$ had no sexual dysfunction, $16.7 \%$ mild sexual dysfunction and $16.7 \%$ had severe sexual dysfunction. In our series, all patients with PD had sexual dysfunction: $23.1 \%$ had mild sexual dysfunction and $76.9 \%$ severe sexual dysfunction. Patients with a stroke history had the following frequencies: $37.5 \%$ severe sexual dysfunction, $37.5 \%$ mild sexual dysfunction and $25 \%$ none at all (Figure 1).

In relation to sexual satisfaction, $59 \%$ of women reported impairment while only $40 \%$ of men did (Figure 2).

With reference to orgasm, this was altered in $60 \%$ of female patients but only in $40 \%$ of male patients (Figure 3).

Table 1. Population characteristics.

\begin{tabular}{|c|c|c|}
\hline Variable & Controls $(n=29)$ & Patients $(n=42)$ \\
\hline Age (years) & $49.4( \pm 19.3)$ & $53.8( \pm 11.24)$ \\
\hline \multirow{2}{*}{ Gender } & Male: $41.4 \%(n=12)$ & Male: $47.6 \%(n=20)$ \\
\hline & Female: $58.6 \%(n=9)$ & Female: $52.4 \%(n=22)$ \\
\hline \multirow{3}{*}{ Age (categories) } & $<40: 38.0 \%(n=11)$ & $<40: 11.8 \%(n=5)$ \\
\hline & 41 a $60: 31.0 \%(n=9)$ & 41 a $60: 59.8 \%(n=25)$ \\
\hline & $>60: 31.0 \%(n=9)$ & $>60: 28.4 \%(n=12)$ \\
\hline \multirow{2}{*}{ Related diseases } & Yes: $51.7 \%(n=15)$ & Yes: $69.0 \%(n=29)$ \\
\hline & No: $48.3 \%(n=14)$ & No: $31.0 \%(n=13)$ \\
\hline \multirow{2}{*}{$\begin{array}{l}\text { Currently a } \\
\text { couple }\end{array}$} & Yes: $69.0 \%(n=20)$ & Yes: $66.7 \%(n=28)$ \\
\hline & No: $31.0 \%(n=9)$ & No: $33.3 \%(n=14)$ \\
\hline \multirow{2}{*}{$\begin{array}{l}\text { Sexual activity } \\
\text { with partner }\end{array}$} & Yes: $65.5 \%(n=19)$ & Yes: $42.9 \%(n=18)$ \\
\hline & No: $34.5 \%(n=10)$ & No: $57.1 \%(n=24)$ \\
\hline \multirow{2}{*}{$\begin{array}{l}\text { Sexual activity in } \\
\text { last } 6 \text { months }\end{array}$} & Yes: $72.4 \%(n=21)$ & Yes: $45.2 \%(n=19)$ \\
\hline & No: $27.6 \%(n=8)$ & No: $54.8 \%(n=23)$ \\
\hline \multirow{2}{*}{$\begin{array}{l}\text { Pharmacological } \\
\text { help }\end{array}$} & Yes: $3.4 \%(n=1)$ & Yes: $4.8 \%(n=2)$ \\
\hline & No: $96.6 \%(n=28)$ & No: $95.2 \%(n=40)$ \\
\hline \multirow{2}{*}{ Depression } & Yes: $13.8 \%(n=4)$ & Yes: $47.6 \%(n=20)$ \\
\hline & No: $86.2 \%(n=25)$ & No: $52.4 \%(n=22)$ \\
\hline
\end{tabular}


Table 2. Population characteristics by entity.

\begin{tabular}{|c|c|c|c|c|}
\hline Variable & $\operatorname{ALS}(n=9)$ & $\mathrm{PD}(\mathrm{n}=8)$ & $M S(n=12)$ & CVDs $(n=8)$ \\
\hline Age & $52.8( \pm 10.8)$ & $62.6( \pm 7.4)$ & $44.7( \pm 8.55)$ & $54.1( \pm 10.59)$ \\
\hline \multirow{2}{*}{ Gender } & Male: $44.4 \%$ & Male: $62.5 \%$ & Male:33.3\% & Male: $50.0 \%$ \\
\hline & Female: $55.6 \%$ & Female: $37.5 \%$ & Female: $66.7 \%$ & Female: $50.0 \%$ \\
\hline \multirow{3}{*}{ Age (categories) } & $<40: 0.0 \%$ & $<40: 0.0 \%$ & $<40: 33.3 \%$ & $<40: 12.5 \%$ \\
\hline & 41 a $60: 66.7 \%$ & 41 a $60: 37.5 \%$ & 41 a $60: 66.7 \%$ & 41 a $60: 75.0 \%$ \\
\hline & $>60: 33.3 \%$ & $>60: 62.5 \%$ & $>60: 0.0 \%$ & $>60: 12.5 \%$ \\
\hline \multirow{2}{*}{ Related diseases } & Yes: $66.7 \%$ & Yes: $75.0 \%$ & Yes: $75.0 \%$ & Yes:100.0\% \\
\hline & No: $33.3 \%$ & No: $25.0 \%$ & No: $25.0 \%$ & No: $0.0 \%$ \\
\hline \multirow{2}{*}{ Sexual activity in last 6 months } & Yes: $33.3 \%$ & Yes: $25.0 \%$ & Yes: $75.0 \%$ & Yes: $50.0 \%$ \\
\hline & No: $66.7 \%$ & No: $75.0 \%$ & No: $25.0 \%$ & No: $50.0 \%$ \\
\hline \multirow{2}{*}{ Pharmacological help } & Yes: $0.0 \%$ & Yes: $0.0 \%$ & Yes: $8.3 \%$ & Yes: $12.5 \%$ \\
\hline & No: $100.0 \%$ & No: $100.0 \%$ & No: $91.7 \%$ & No: $87.5 \%$ \\
\hline \multirow{2}{*}{ Depression } & Yes: $66.7 \%$ & Yes: $50.0 \%$ & Yes: $25.0 \%$ & Yes: $50.0 \%$ \\
\hline & No:33.3\% & No: $50.0 \%$ & No: $75.0 \%$ & No: $50.0 \%$ \\
\hline \multirow{4}{*}{ Disability } & WT Dis: $0.0 \%$ & WT Dis: $25.0 \%$ & WT Dis: $0.0 \%$ & WT Dis: 0\% \\
\hline & Mild: 11.1\% & Mild: $62.5 \%$ & Mild: $8.3 \%$ & Mild: $75.0 \%$ \\
\hline & Moderate: $66.7 \%$ & Moderate: $12.5 \%$ & Moderate: $66.7 \%$ & Moderate: $25.0 \%$ \\
\hline & Severe: $22.2 \%$ & Severe: $0.0 \%$ & Severe: $25.0 \%$ & Severe: $0.0 \%$ \\
\hline
\end{tabular}

ALS: amyotrophic lateral sclerosis; PD: Parkinson's disease; MS: multiple sclerosis; CVDs: cerebrovascular diseases; WT Dis: without disability.

SEXUAL DYSFUNCTION BY ENTITY

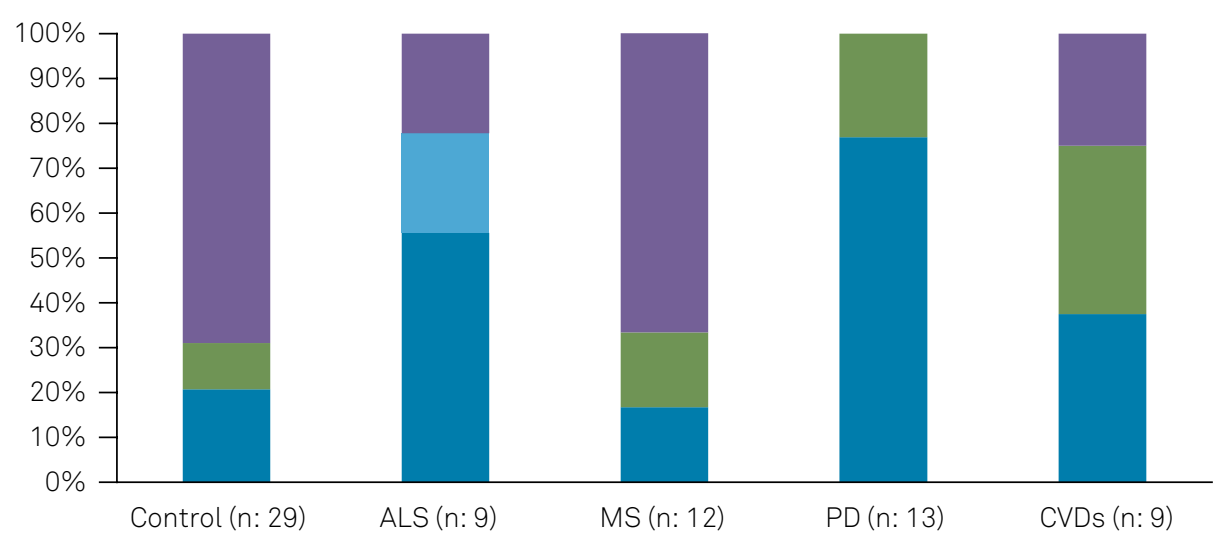

- Severe Sex Dysf Moder Sex Dysf Mild Sex Dysf $\square$ Without Sex Dysf

ALS: amyotrophic lateral sclerosis; PD: Parkinson's disease; MS: multiple sclerosis; CVDs: cerebrovascular diseases.

Figure 1. Sexual dysfunction by entity.

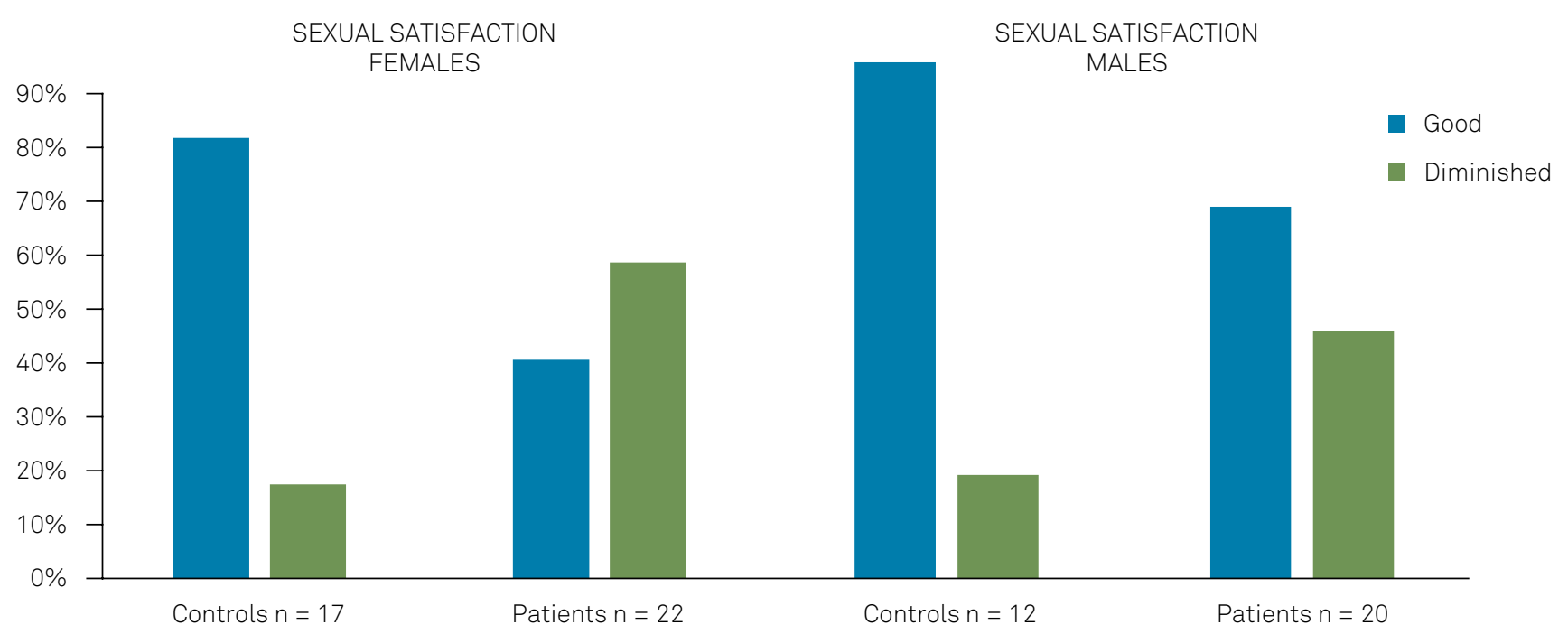

Figure 2. Sexual satisfaction in females and males. 


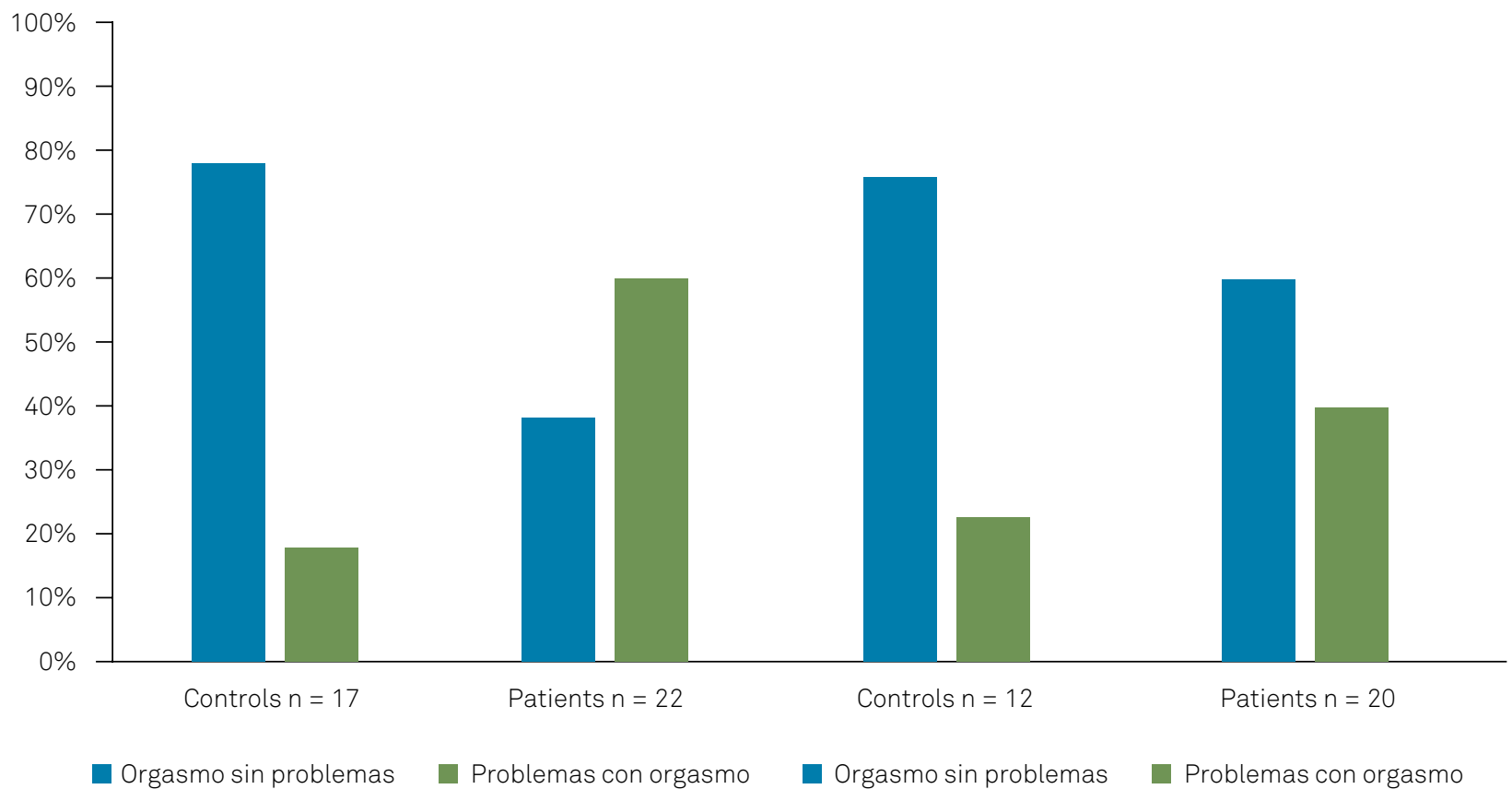

Figure 3. Orgasm function in females and males.

\section{DISCUSSION}

From our study population analysis, we can conclude that disability was the main variable associated with sexual dysfunction, as has already been reported ${ }^{1,2}$. This is a complex relationship that cannot be explained by means of a unique pathophysiological mechanism. For example, in ALS, sexual dysfunction is most likely secondary to motility restriction due to muscular atrophy and motor disability per se, as well as dyspnea and depression. In MS patients, on the other hand, strategic CNS lesions affecting anatomic centers related to sexuality are probably responsible for sexual impairment, along with social stigmatization, and both sensory and motor dysfunction. Finally, in PD and stroke, adverse effects of commonly-used treatments like beta-blockers and dopamine agonists also need to be considered as possible etiologies. Beyond the probable mechanisms of each disease, living with a chronic pathology or its sequelae implies that a considerable amount of time is spent in rehabilitation or reminders of the disease (such as medical appointments, complementary studies, etc.), which may have a negative impact on personal relationships and, of course, sexuality ${ }^{19}$.

Of the chronic neurological diseases considered in our study, ALS patients were the most sexually disabled.
As already stated, this may be secondary to mobility impairment, forced vital capacity reduction and the burden of bearing a poor prognosis disease. Noticeably, MS patients' rating was similar to controls, possibly due to broader coping abilities related to a younger age. Therefore, not surprisingly in PD, all patients had at least some degree of sexual dysfunction.

One finding that captured our attention was the gender differences observed. In our population, equally disabled women had higher sexual dysfunction scores than men. It is possible that sexual dysfunction affects genders differently, but it is certainly not clear how chronic diseases with similar motor impairment can affect females to a greater extent ${ }^{35,36}$.

Our findings confirm the intuitive association of sexual dysfunction in patients with some of the most disabling chronic neurologic diseases. We believe that the performance of other studies targeted to a better understanding of the pathologic pathways involved, and the offering of better therapeutic options, would be highly advisable ${ }^{37}$. We therefore believe that sexuality should be addressed during regular consultations, because through the diagnosis of sexual problems, neurologists can offer both advice and treatment, thus improving the patient's quality of living.

\section{References}

2. Dalteg T, Benzein E, Fridlund B, Malm D. Cardiac disease and its consequences on the partner relationship: a systematic review. Eur J Cardiovasc Nurs. 2011 Sep;10(3):140-9. https://doi.org/10.1016/j.ejcnurse.2011.01.006 
3. Dehghan-Nayeri N, Khakbazan Z, Ghafoori F, Nabavi SM. Sexual dysfunction levels in iranian women suffering from multiple sclerosis. Mult Scler Relat Disord. 2016;49:53-4. https://doi.org/10.1016/j.msard.2017.01.005

4. Quarracino C, Rey RC, Rodríguez GE. [Amyotrophic Lateral Sclerosis (ALS): monitoring and treatment]. Neurología Argentina. $2014 \mathrm{Abr}-$ Jun; 91:95-2. Spanish. https://doi.org/10.1016/j.neuarg.2014.02.004

5. Wasner M, Bold U, Vollmer TC, Borasio GD. Sexuality in patients with amyotrophic lateral sclerosis and their partners. J Neurol. 2004 Apr;251(4):445-8. https://doi.org/10.1007/s00415-004-0351-1

6. Fernández Liguori N., Seifer G, Villa AM, Garcea O. [Fingolimod: a new approach in the treatment of multiple sclerosis]. Neurología Argentina. 2012 Jul-Sep;4(3): 144-51. Spanish. https://doi.org/10.1016/j.neuarg.2012.05.002

7. Scollo SD, Emanuel F, Crimi D, Rodriguez-Quiroga SA, Christie C, Diaz-Arangunde $V$ et al. Clinical progression of Parkinson's disease: $A$ retrospective analysis in a specialized consulting room in movement disorders. Neurología Argentina. 2016 Oct-Dec.;8(4):258-62. Spanish. https://doi.org/10.1016/j.neuarg.2016.05.002

8. Bronner G, Royter V, Korczyn AD, Giladi N. Sexual dysfunction in Parkinson's disease. J Sex Marital Ther. 2004 Mar-Apr;30(2):95-105. https://doi.org/10.1080/00926230490258893

9. Rodriguez GE, Gonzalez LA, Luraschi AN, Melamud L, Lepera SM, Rey RC. [Care of acute stroke in a stroke unit and in a general Ward]. Neurología Argentina. 2010 Jan-Mar;2(1)8-13. Spanish. https://doi.org/10.1016/S0325-0938(10)70003-9

10. Lopez AD, Mathers CD, Ezzati M, Jamison DT, Murray CJ. Global and regional burden of disease and risk factors, 2001: systematic analysis of population health data. Lancet. 2006 May;367(9524):1747-57. https://doi.org/10.1016/S0140-6736(06)68770-9

11. Nilsson MI, Fugl-Meyer K, Koch L, Ytterberg C. Experiences of sexuality six years after stroke: a qualitative study. J Sex Med. 2017 Jun;14(6):797-803. https://doi.org/10.1016/j.jsxm.2017.04.061

12. Carrillo-González GM, Sánchez-Herrera B, Chaparro-Díaz L. Chronic disease and sexuality. Invest Educ Enfermeria. 2013 MayAug;31(2):304-5.

13. Verschuren JE, Enzlin P, Dijkstra PU, Geertzen JHB, Dekker R. Chronic disease and sexuality: a generic conceptual framework. J Sex Res. 2010 Mar;47(2):153-70. https://doi.org/10.1080/00224491003658227

14. Holstege G, Georgiadis JR, Paans AMJ, Meiners, LC, Graaf FHCE, Reinders AATS. Brain activation during human male ejaculation. J Neurosci. 2003 Oct;23(27):9185-93. https://doi.org/10.1523/JNEUROSCI.23-27-09185.2003

15. Arnow BA, Desmond JE, Banner LL, Glover GH, Solomon A, Polan ML et al. Brain activation and sexual arousal in healthy, heterosexual males. Brain. 2002 May;125(5):1014-23. https://doi.org/10.1093/brain/awf108

16. Redouté J, Stoléru S, Grégoire MC, Costes N, Cinotti L, Lavenne F et al. Brain processing of visual sexual stimuli in human males. Hum Brain Mapp. 2000 Nov;11(3)162-177.

17. Georgiadis JR, Kortekaas R, Kuipers R, Nieuwenburg A, Pruim J, Reinders AA et al. Regional cerebral blood flow changes associated with clitorally induced orgasm in healthy women. Eur J Neurosci. 2006 Dec;24(11):3305-16. https://doi.org/10.1111/j.1460-9568.2006.05206.x

18. Meston CM, Frohlich PF. The neurobiology of sexual function. Arch Gen Psychiatry. 2000 Nov;57(11):1012-30. https://doi.org/10.1001/archpsyc.57.11.1012

19. Frohlich PF, Meston CM. Evidence that serotonin affects female sexual functioning via peripheral mechanisms. Physiol Behav. $2000 \mathrm{Nov}$;11(34):383-93. https://doi.org/10.1016/S0031-9384(00)00344-9

20. Meston CM. Sympathetic nervous system activity and female sexual arousal. Am J Cardiol. 2000 Jul;86(2 2A):30F-4F. https://doi.org/10.1016/S0002-9149(00)00889-4
21. Waldinger MD, Berendsen HH, Blok BF, Olivier B, Holstege G. Premature ejaculation and serotonergic antidepressants-induced delayed ejaculation: the involvement of the serotonergic system. Behav Brain Res. 1998 May;92(2):111-8. https://doi.org/10.1016/S0166-4328(97)00183-6

22. Kandeel FR, Koussa VK, Swerdloff RS. Male sexual function and its disorders: physiology, pathophysiology, clinical investigation, and treatment. Endocr Rev. 2001 Jun;22(3):342-88. https://doi.org/10.1210/edrv.22.3.0430

23. Basson R, Schultz WW. Sexual sequelae of general medical disorders. Lancet. 2007 Feb;369(9559):409-24 https://doi.org/10.1016/S0140-6736(07)60197-4

24. Hulter BM, Lundberg PO. Sexual function in women with advanced multiple sclerosis. J Neurol Neurosurg Psychiatry. 1995 Jul;59(1):836. https://doi.org/10.1136/jnnp.59.1.83

25. Fode M, Krogh-Jespersen S, Brackett NL, OhL DA, Lynne CM, Sønksen J. Male sexual dysfunction and infertility associated with neurological disorders. Asian J Androl. 2001 Jan;14(1):61-8. https://doi.org/10.1038/aja.2011.70

26. Sipski ML, Alexander CJ, Rosen R. Sexual arousal and orgasm in women: effects of spinal cord injury. Ann Neurol. 2001 Jan;49(1):3544. https://doi.org/10.1002/1531-8249(200101)49:1<35::AID-ANA8 $>3.0 . \mathrm{CO} ; 2-\mathrm{J}$

27. Cedarbaum JM, Stambler N, Malta E, Fuller C, Hilt D, Thurmond $B$ et al. The ALSFRS-R: a revised ALS functional rating scale that incorporates assessments of respiratory function. J Neurol Sci1999 Oct;169(1-2):13-21. https://doi.org/10.1016/S0022-510X(99)00210-5

28. Salas Campos T, Rodríguez-Santos F, Esteban J, Cordero Vázquez PC, Mora Pardina JS, Cano Carmona A. Adaptación española de la escala revisada de valoración funcional de la esclerosis lateral amiotrofica. 2010 [cited 2017 Aug 15]. Available from: http://www. fundela.es/documentacion/publicaciones/general/adaptacionespanola-de-la-escala-revisada-de-valoracion-funcional-de-laesclerosis-lateral-amiotrofi/

29. Meyer-Moock S, Feng YS, Maeurer M, Dippel FW, Kohlmann T. Systematic literature review and validity evaluation of the Expanded Disability Status Scale (EDSS) and the Multiple Sclerosis Functional Composite (MSFC) in patients with multiple sclerosis. BMC Neurol. 2014 Mar;14(1):58. https://doi.org/10.1186/1471-2377-14-58

30. Goetz CG, Tilley BC, Shaftman SR, Stebbins GT, Fahn S, MartinezMartin P et al. Movement Disorder Society-sponsored revision of the Unified Parkinson's Disease Rating Scale (MDS-UPDRS): scale presentation and clinimetric testing results. Mov Disord. 2008 Nov;23(15):2129-70. https://doi.org/10.1002/mds.22340

31. Banks JL, Marotta CA. Outcomes validity and reliability of the modified Rankin scale: implications for stroke clinical trials: a literature review and synthesis. Stroke. 2007 Mar;38(3):1091-6. https://doi.org/10.1161/01.STR.0000258355.23810.c6

32. Rosen RC, Cappelleri JC, Gendrano N 3rd. The International Index of Erectile Function (IIEF): a state-of-the-science review. Int J Impot Res. 2002 Aug;14(4):226-44. https://doi.org/10.1038/sj.ijir.3900857

33. Meston CM. Validation of the Female Sexual Function Index (FSFI) in women with female orgasmic disorder and in women with hypoactive sexual desire disorder. J Sex Marital Ther. 2003 Jan-Feb;29(1):39-46. https://doi.org/10.1080/713847100

34. Beck AT, Ward CH, Mendelson M, Mock J, Erbaugh J. An inventory for measuring depression. Arch Gen Psychiatry. 1961 Jun;4(6):561-71. https://doi.org/10.1001/archpsyc.1961.01710120031004

35. Alsop R, Fitzsimons A, Lennon K. Theorizing gender: an introduction. Hoboken: John Wiley; 2002.

36. Peplau LA. Human sexuality: how do men and women differ: relationships aggression. Curr Dir Psychol Sci. 2003;12(2):37-41.

37. Pieters R, Kedde H, Bender J. Training rehabilitation teams in sexual health care: A description and evaluation of a multidisciplinary intervention. Disabil Rehabil. 2018 Mar;40(6):732-9. https://doi.org/10.1080/09638288.2016.1271026 